\title{
Note on the Translation
}

This book is a reflection on forms of life and, in particular, how critique or criticism of forms of life is possible and what it involves. Since the notion of Kritik is of central importance for the present study and the German term can be translated either as "critique" or "criticism," it seemed advisable for the sake of clarity to adopt a consistent policy on the use of the English terms throughout the book. Thus, as a general rule Kritik has been translated here as "criticism" when it refers to the philosophical activity of criticizing forms of life in general, and "critique" has been reserved for the more specific sense of a strategy or line of criticism of a particular form of life, as in "Hegel's critique of the romantic conception of marriage" or "Marx's critique of capitalism."

The other term in the book's German title, "Lebensform," can be translated in a variety of ways, ranging from "way of life," "habit of life," and "lifestyle" to "lifeform." Since the term is central to the project pursued in this book-indeed, one of its central concerns is to develop and defend a philosophical conception of what constitutes a Lebensform-it seemed advisable to translate it uniformly as "form of life," and to reserve such terms as "way of life" and "lifestyle" for phenomena with which it is explicitly contrasted in Chapter 1 . The one exception to the policy of translating "Lebensform" as "form of life" is where the author speaks of the Lebensform of giraffes or lions. In this case the biologically connoted term "lifeform" is a more appropriate translation, since animals do not have forms of life in the sense developed in this study. 
A particular challenge for translation was posed by the author's extensive use of Hegelian terms (reflecting her understanding of critical theory as a Hegelian project). One of the examples of criticism discussed in detail in the book is Hegel's critique of bürgerliche Gesellschaft as a workoriented society. "Bürgerliche Gesellschaft" is standardly rendered as "civil society" in translations of Hegel's Philosophy of Right; however, aside from having quite different connotations in contemporary political philosophy, the term "civil society" fails to capture the proto-Marxist elements of Hegel's critique of work-oriented society highlighted in the present study. Hence it was decided to translate "bürgerliche Gesellschaft" as "bourgeois civil society" with reference to Hegel but as "bourgeois society" in discussions of Marx, for whom the term "bourgeois" has, of course, strong connotations of social class and class conflict that it lacks for Hegel. It also seemed advisable to translate "bürgerliche Ehe" in discussions of Hegel's critique thereof with "bourgeois civil marriage," rather than with the more neutral "civil marriage," to signal that Hegel is referring to a historically specific formation that did not exist in this form earlier in history (rather than to the institution of civil marriage as such).

Other Hegelian terms that feature centrally and call for special treatment are "Sittlichkeit," "Wirklichkeit," "Aufhebung," and "Entzweiung." Hegel's notion of Sittlichkeit is universally translated as "ethical life," a practice that is retained here since it presents no problems of comprehension for informed readers. However, to follow the practice of translating the related adjective "sittlich" simply as "ethical" would have been potentially quite misleading, since the English word lacks the social-institutional connotations of "sittlich" that the author wishes to highlight; moreover, for many readers it might have Aristotelian associations (of an individual ethics of virtue and the good life) that she wishes to avoid, or it might invoke the philosophical contrast between "ethical" and "moral" forms of judgment and criticism that she explicitly criticizes. Thus, it seemed imperative to translate "sittlich" with adjectival phrases that make the connection to Hegel's notion of ethical life explicit, so that, for example, "sittliche Norm" is rendered as "norm of ethical life" and "sittliche Institution" as "institution of ethical life."

The term "Wirklichkeit" is used in the present study in its general meaning of "reality" but also, with reference to Hegel, in the specifically Hegelian sense of "actuality." For Hegel, an entity can be real or possess 
reality without being actual or exhibiting actuality. Thus, a human child is a real human being but, insofar as it has yet to develop the full potential implicit in the concept of a human being, and hence does not yet correspond to its concept, it lacks actuality. Accordingly, where "Verwirklicbung" refers to the process of development though which an entity actualizes the potential implicit in its concept in this Hegelian sense it is translated as "actualization" (and, accordingly, the verb "verwirklichen" as "actualize" and the adjective "wirklich" as "actual").

Generations of Hegel translators have despaired of finding an English word that adequately captures the meaning of the central Hegelian concept of "Aufhebung," which refers to a process of development in which a higher or more advanced stage both supersedes or annuls the previous stage while nevertheless also preserving its essential features in a new constellation. For this reason, the term specifically invented for this purpose, "sublation," and the associated verb "sublate," continue to be used in contemporary translations and discussions of Hegel and hence are also retained here. However, other invented words from earlier generations of translations of Hegel that serve more to obscure than to clarify the meaning of his thought have been avoided. A case in point is the term "Entzweiung," which is translated here with "division" (and the corresponding verb "entzweien" with "divide") rather than in the traditional way as "diremption" (even though the latter is still occasionally encountered in discussions of Hegel in English).

Finally, a point of translation that should be kept in mind when reading this book concerns what is meant by speaking of the "success" of problemsolving practices and, by extension, of the "success" of forms of life as such. In relation to forms of life and to the practices that, according to the analysis developed here, are constitutive of them, "success" means something more than the instrumental realization of a purpose or a goal that could be specified independently of the practice or form of life in question. "Success" in this more demanding sense of "Gelingen" (as opposed to mere "Erfolg") means that a practice or form of life satisfies criteria that are contained in its concept and hence are (implicitly) posited with it, so that the successful development can be reconstructed in rational terms. Moreover, according to the analysis developed in this book, the criteria in question always also have a normative meaning, so that the "success" of forms of life and their constitutive practices also has the normative 
connotation of "going well" or "turning out well," as opposed to the merely functional sense of "working out." Where it seemed imperative to highlight these noninstrumental and nonfunctional connotations of "Gelingen" and the corresponding adjective "gelungen," "succeed" and cognate words have been supplemented with the verbs "turn out well" and "flourish" and cognates. 